\title{
18. DEEP-MARINE ORIGIN OF EQUANT SPAR CEMENTS IN OLIGOCENE-MIOCENE PERIREEF BOUNDSTONES, LEG 101, SITE 635, NORTHEAST PROVIDENCE CHANNEL, BAHAMAS ${ }^{1}$
}

\author{
R. P. Freeman-Lynde, ${ }^{2}$ W. R. McClain ${ }^{2}$ and K. C. Lohmann ${ }^{3}$
}

\begin{abstract}
Oligocene-Miocene perireef boundstone clasts buried in slumped canyon-fill sediments drilled at Hole 635B in Northeast Providence Channel during Leg 101 contain petrographic evidence of shallow-marine diagenesis, including abundant cloudy, isopachous, very fine to medium, radiaxial fibrous cement in shelter and intraparticle porosity. A single microsample of this cement has a stable oxygen and carbon isotopic composition $\left(-1.1 \% 0 \delta^{18} \mathrm{O},+2.8 \% 0 \delta^{13} \mathrm{C}\right)$ that is consistent with precipitation from warm, shallow-marine water. This isotopic composition also lies in the isotopic field defined for petrographically similar cement in bank-interior limestones exposed nearby on the Bahama Escarpment. Effects of vadose and meteoric phreatic diagenesis are absent.

Following shallow-marine diagenesis, these boundstone clasts were transported to the deep $(\sim 3500 \mathrm{~m})$ axis of Northeast Providence Channel and exposed to deep-marine waters, which appear to have initiated deep-marine diagenesis. The principal results of deep-marine diagenesis were dissolution of unstable, presumably aragonitic, grains and reprecipitation of carbonate into both newly opened molds and partially filled primary pores as clear, fine to medium, equant calcite spar. Stable oxygen and carbon isotopic compositions $\left(+2.0 \% \delta^{18} \mathrm{O},+3.6 \% 0 \delta^{13} \mathrm{C}\right.$, and $+2.6 \% 0 \delta^{18} \mathrm{O}$, $\left.+3.9 \% 0 \delta^{13} \mathrm{C}\right)$ of two microsamples of this equant spar are significantly ${ }^{18} \mathrm{O}$-enriched $(>3 \%)$ relative to shallow-marine cements in the same samples, which is consistent with precipitation in equilibrium with colder, deep-marine waters. Isotopic composition of these equant spars is similar to that of deep-marine hardgrounds in Tongue of the Ocean and Northwest Providence Channel, and to Pleistocene equant spars in Early and middle Cretaceous shallow-water limestones exposed on the Bahama Escarpment.
\end{abstract}

\section{INTRODUCTION}

Shallow-bank carbonates contain significant quantities of equant calcite spar cements precipitated in burial phreatic environments from warm, meteoric or highly evolved connate fluids (Longman, 1980; Scholle and Halley, 1985). Stable oxygen and carbon isotopic compositions and trace-element contents of cements and micrite matrix in Early and middle Cretaceous bankinterior limestones exposed on the Bahama Escarpment, combined with conventional petrography, suggest that equant calcite spar cements in these rocks were precipitated from cold, deepmarine waters in deep-burial zones at the deep seafloor during late diagenesis, not from warm, meteoric or highly evolved connate fluids (Freeman-Lynde et al., 1986).

This paper reports on similar equant calcite spar cements, which we think were precipitated from cold, deep-marine waters into shallow-bank limestones. We base this conclusion on the results of petrographic and stable oxygen and carbon isotope analyses of cements contained in two perireef algal-foraminifer boundstone clasts of Oligocene-Miocene age recovered from Hole 635B in Northeast Providence Channel during Leg 101 (Figs. 1 and 2). After early diagenesis in shallow-marine water, these clasts were transported downslope, where they were encountered in slumped canyon-fill sediments about 7 meters below the seafloor (mbsf) in water depths of nearly $3500 \mathrm{~m}$. This slumped canyon-fill unit is about $60 \mathrm{~m}$ thick at Site 635 and consists of a chaotic mixture of deep-water slope and basin deposits and shallow-platform lithoclasts (including those of our study), with ages ranging from early Pliocene to middle Cenomanian (Austin, Schlager, et al., 1986). Although our data show

\footnotetext{
${ }^{1}$ Austin, J. A., Jr., Schlager, W., et al., 1988. Proc. ODP, Sci. Results, 101: College Station, TX (Ocean Drilling Program).

2 Department of Geology, University of Georgia, Athens, GA 30602.

${ }^{3}$ Department of Geological Sciences, University of Michigan, Ann Arbor, MI
}

that early diagenesis of these clasts occurred syndepositionally in shallow-marine water, we will demonstrate that precipitation of equant calcite spar cements took place during late diagenesis when these clasts were immersed in cold, deep-marine water.

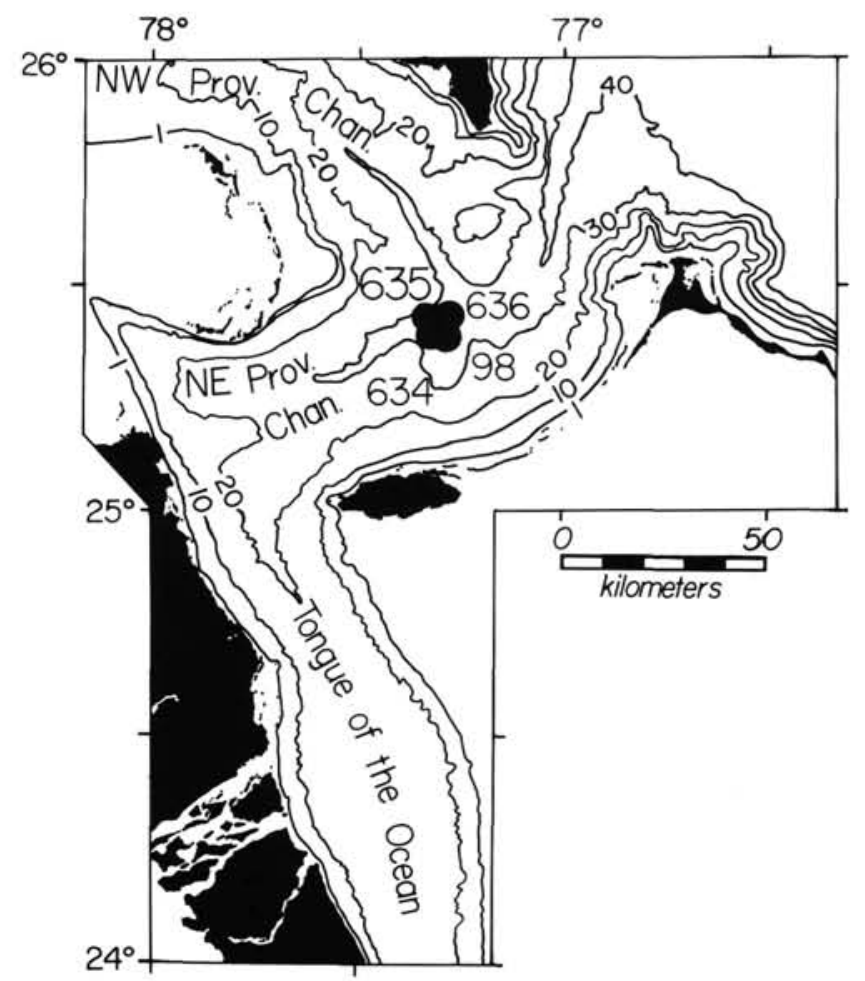

Figure 1. Location of DSDP Site 98 and ODP Sites 634 through 636 in Northeast Providence Channel. Bathymetry taken from Andrews et al. (1970) and Schlager et al. (1976). 


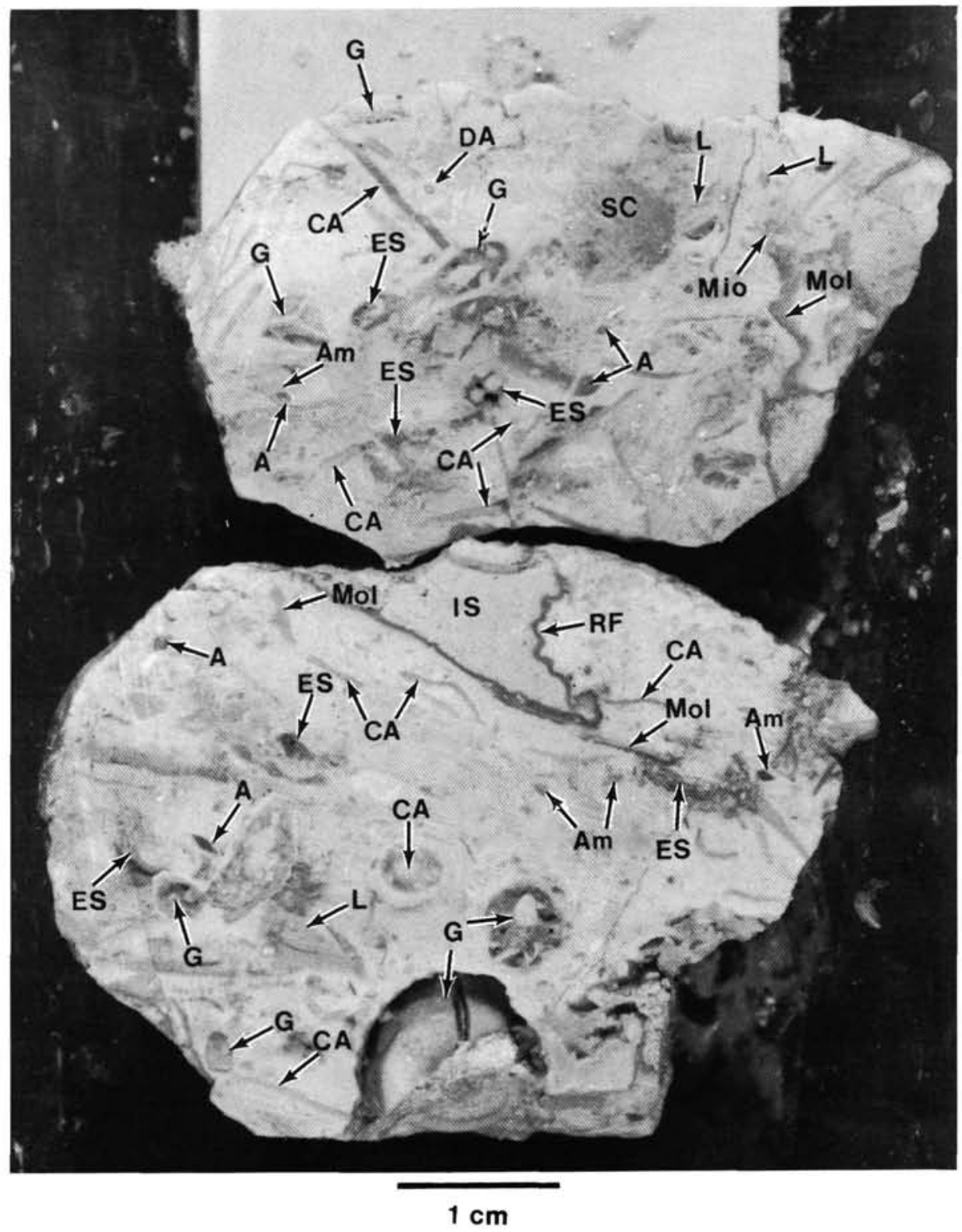

Figure 2. Photograph of Oligocene-Miocene perireef boundstone clasts (Sample 101-635B-2R-2, 44$51 \mathrm{~cm})$. Abundant biogenic grains, including codiacean $(C A)$ and dasycladacean $(D A)$ algae, Amphistegina $(A m)$, alveolinid $(A)$, lepidocyclinid $(L)$ and miogypsinid $(M i o)$ foraminifers, scleractinian coral $(S C)$, mollusk fragments $(\mathrm{Mol})$, and whole gastropod molds $(G)$, are visible. Internal sedimentfilled cavity $(I S)$ in lower clast contains isopachous, radiaxial fibrous cement $(R F)$. Equant spar $(E S)$ occurs in several molds and cavities.

\section{METHODS OF INVESTIGATION}

Conventional petrographic analysis was conducted on polished thin sections using a petrographic microscope. Scanning electron microscopy (SEM) photomicrographs of etched samples were obtained with the University of Georgia's Philips 505 Scanning Electron Microscope to investigate cement characteristics. Stable oxygen and carbon isotopic compositions (Table 1) were determined for one microsample of shallow-marine, cloudy, isopachous, radiaxial cement and two microsamples of deep-marine, clear, equant calcite spar cement. Microsampling was performed using a drilling assembly coupled to a standard binocular microscope. Samples were mounted on a micropositioning X-Y translation stage to extract about $0.1 \mathrm{mg}$ of powder for analyses. Drill bits varied from 0.15 to $0.7 \mathrm{~mm}$ in diameter and were matched to component width. Isotope compositions were determined with a VG Micromass $602 \mathrm{E}$ ratio mass spectrometer. Microsamples were vacuum-roasted at $380^{\circ} \mathrm{C}$ to remove volatile organic contaminants and reacted with anhydrous phosphoric acid at $50^{\circ} \mathrm{C}$ in an on-line, gas-extraction system coupled directly to the mass spectrometer inlet. Isotopic ratios were measured relative to the University of Michigan Stable Isotope Laboratory Standard Gas (KIS-I), converted to PDB, and corrected for $\delta^{17} \mathrm{O}$ as described by Craig (1957).

\section{PERIREEF DEPOSITION AND SHALLOW-MARINE DIAGENESIS}

Boundstone clasts of Oligocene-Miocene age recovered from Hole 635B in Northeast Providence Channel contain abundant biogenic grains, which suggests deposition in a perireef setting (Figs. 2 through 4). These include large benthic foraminifers (Amphistegina, alveolinids, lepidocyclinids, miogypsinids), scleractinian coral fragments, encrusting foraminifers and bryozoans, calcareous algae (codiacean, dasycladacean, coralline), echinoid spines and plates, gastropod shells (both fragmented and whole), abundant comminuted skeletal grains, and rare planktonic fora- 
Table 1. Stable oxygen and carbon isotopic compositions for cement microsamples from Hole 635B.

\begin{tabular}{ccc}
\hline Sample (cm) & $\begin{array}{c}\delta^{18} \mathrm{O} \\
(\% 0 \mathrm{PDB})\end{array}$ & $\begin{array}{c}\delta^{18} \mathrm{C} \\
(\% 0 \mathrm{PDB})\end{array}$ \\
\hline $101-635 \mathrm{~B}-2 \mathrm{R}-2,44-47$ \\
$\begin{array}{c}\text { (spar) } \\
\text { 101-635B-2R-2, 47-51 } \\
\text { (spar) }\end{array}$ & +2.6 & +3.9 \\
$\begin{array}{c}101-635 \mathrm{~B}-2 \mathrm{R}-2,47-51 \\
\text { (radiaxial) }\end{array}$ & -1.1 & +2.6 \\
\hline
\end{tabular}

minifers. Large benthic foraminifers are closely associated with coral reefs, and their co-occurrence with scleractinian coral fragments indicates a tropical, shallow-marine (less than 5-20 m water depth) environment of deposition for these boundstone clasts (Murray, 1973; Frost and Langenheim, 1974; Ross, 1979; Frost, 1981).
Grains were bound chaotically in micrite, with the resulting formation of abundant shelter pores and cavities that vary in size from $200 \mu \mathrm{m}$ to $10 \mathrm{~mm}$ (Figs. 2 through 4 ). The binding nature of the matrix is illustrated in a few cases by grains stuck to the sides of cavities, as indicated by geopetal structures (Fig. 3), as well as by a fracture filled with shallow-marine cement. Intraparticle porosity is also abundant in these perireef boundstones, but interparticle porosity is absent because mud fills the space between grains.

Early diagenesis of the perireef sediments appears to have occurred syndepositionally in shallow-marine water. Shelter and intragranular porosity contains abundant cloudy, isopachous, very fine to medium $(10-75 \mu \mathrm{m})$, radiaxial fibrous and bladed cements as early fillings (Figs. 2 through 4). Interpretation of such cloudy, isopachous, radiaxial fibrous and bladed cements as shallow-marine is consistent with other studies (Longman, 1980; Moldovanyi and Lohmann, 1984; Prezbindowski, 1985; Freeman-Lynde et al., 1986). Their fibrous and bladed nature indicates that these cements were originally high-magnesium calcite or aragonite (Longman, 1980). Sample 101-635B-2R-2,
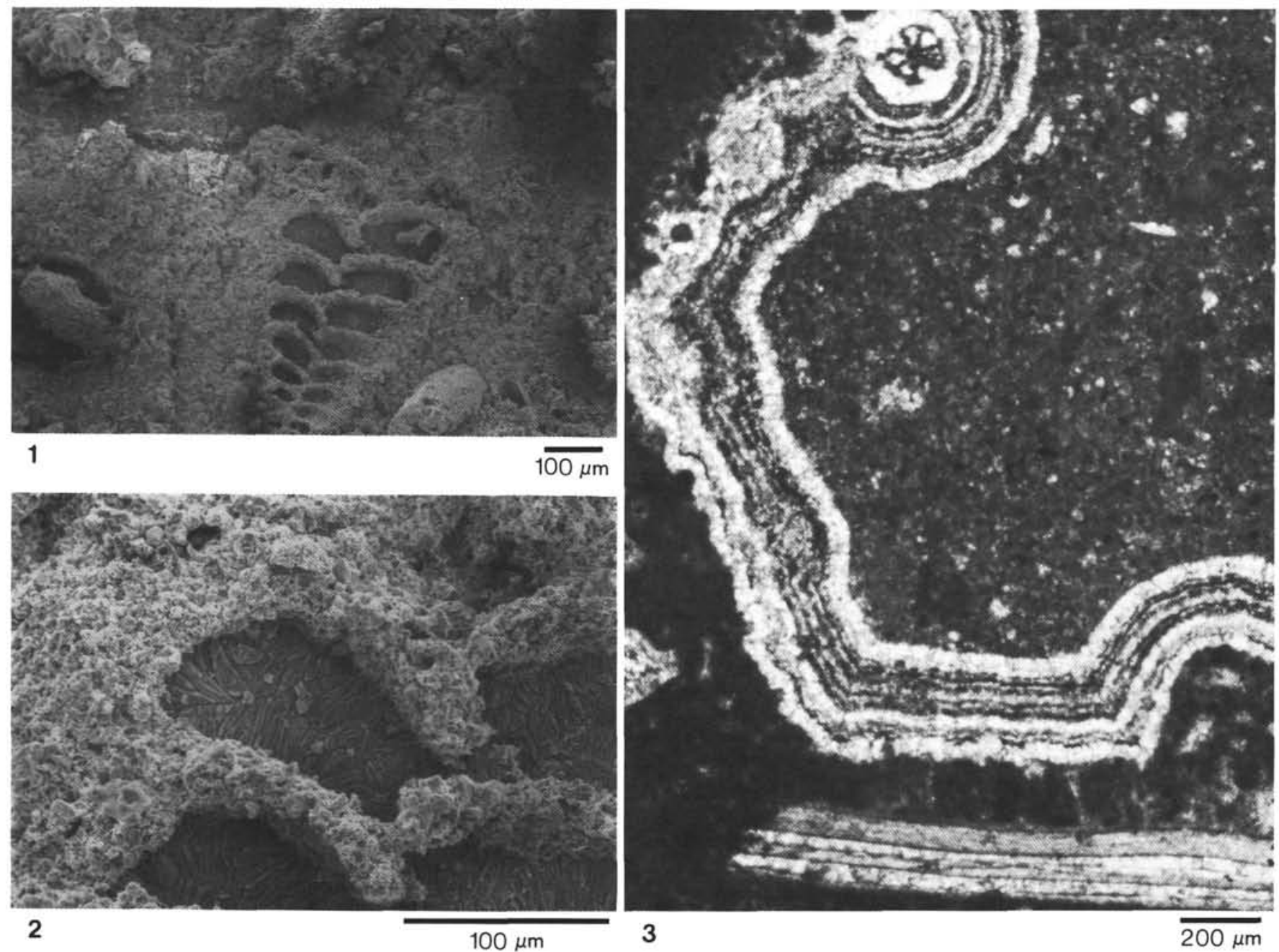

2

$100 \mu \mathrm{m}$

Figure 3. Thin-section and SEM photomicrographs illustrating cloudy, isopachous, very fine to medium, radiaxial fibrous cement precipitated from shallow-marine water, and primary porosity (shelter, intraparticle) in Oligocene-Miocene perireef boundstone clast (Sample 101-635B-2R-2, 47-51 cm), recovered from canyon-fill sediments. 1. SEM photomicrograph of radiaxial fibrous cement filling intraparticle porosity in textulariid foraminifer. Micritic nature of interparticle matrix is evident. Fragment of echinoid spine occurs to the right of the foraminifer. 2. Enlargement of top chambers of textulariid foraminifer, shown in SEM photomicrograph (1), containing intraparticle porosity-filling radiaxial fibrous cement. 3. Thin-section photomicrograph of multiple generation of radiaxial fibrous cement (defined by varying degrees of cloudiness) lining internal sediment-filled cavity. Several grains were attached to the side of the cavity before cementation. Mollusk fragment is visible at the bottom of the cavity. (Crossed nicols.) 


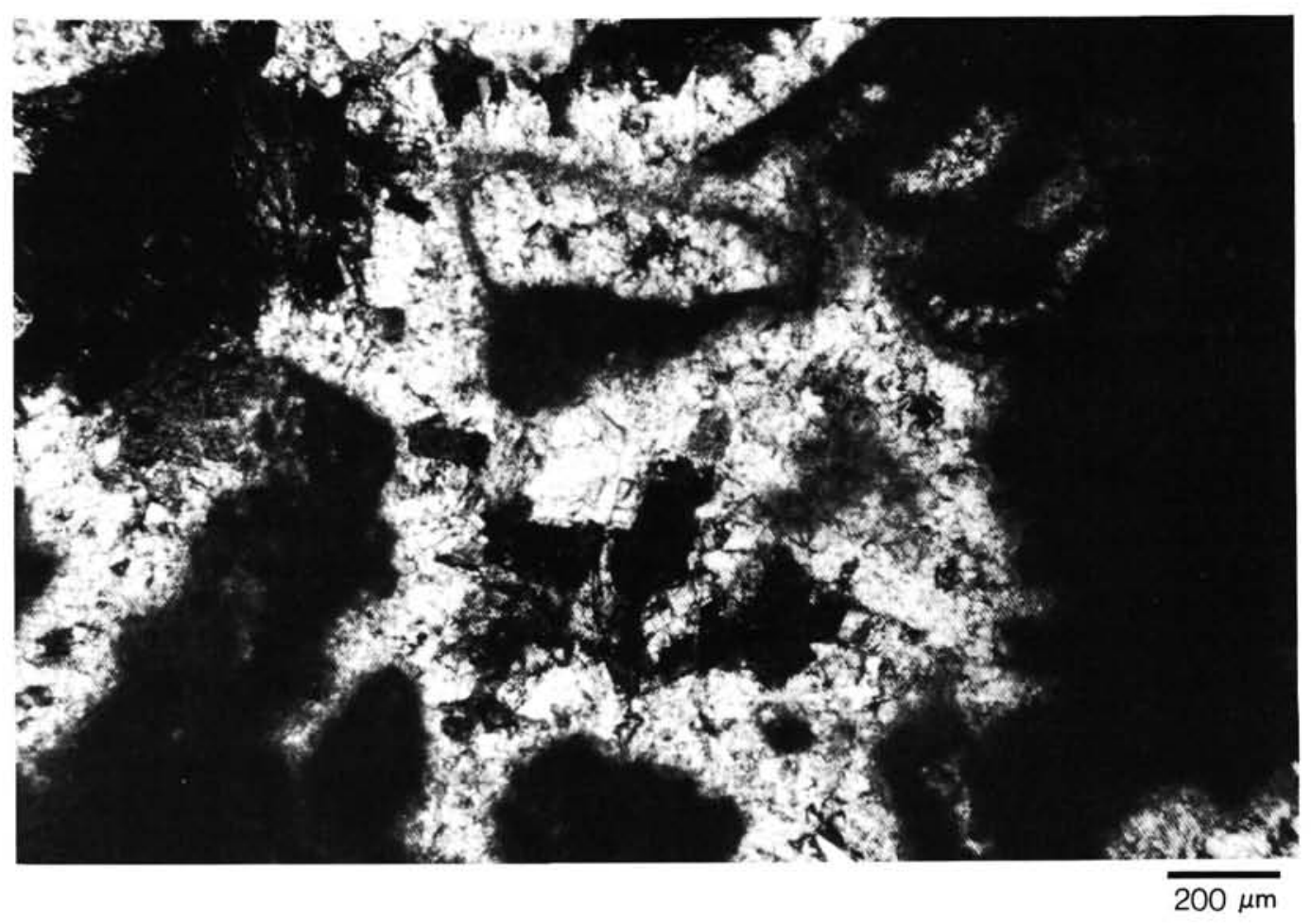

Figure 4. Thin-section photomicrograph showing early, shallow-marine, radiaxial fibrous cement and late, deepmarine, equant spar cement in completely to partially filled shelter porosity in Oligocene-Miocene perireef boundstone clast (Sample 101-635B-2R-2, 44-47 cm), recovered from canyon-fill sediments. Note small moldic grain filled only with fine equant spar in upper center part of photomicrograph. (Crossed nicols.)

$47-51 \mathrm{~cm}$, contains several pores that exhibit multiple generations of isopachous, fine to medium $(50-75 \mu \mathrm{m})$, radiaxial fibrous cement having a distinct stratigraphy defined by different degrees of cloudiness (Fig. 3). This multiple generation cement occurs in layers up to $0.3 \mathrm{~mm}$ thick.

Stable oxygen and carbon isotope analyses $\left(-1.1 \% \delta^{18} \mathrm{O}\right.$, $+2.8 \% 0 \delta^{13} \mathrm{C}$ ) (Table 1 ; Fig. 5 ) of a single microsample support a shallow-marine origin for these radiaxial fibrous cements. The isotopic composition of this microsample is in equilibrium with "warm" $\left(15^{\circ}-25^{\circ} \mathrm{C}\right)$, shallow-marine water $\left(\delta^{18} \mathrm{O}_{\mathrm{SMOw}}=0\right)$, assuming that the original isotopic composition was preserved during stabilization of this originally high-magnesium calcite or aragonite cement. This isotopic composition lies in the isotopic field determined for petrographically similar cements in bankinterior limestones exposed nearby on the Bahama Escarpment (Freeman-Lynde et al., 1986).

We do not believe that diagenesis of these perireef boundstone clasts in meteoric phreatic or vadose environments occurred. The only features of these clasts that might have developed in such environments are stabilization of their originally high-magnesium or aragonite shallow-marine cements (Figs. 2 through 4) to calcite, their moldic porosity, and their equant spar cements (Figs. 2, 4, and 6). However, we feel that these features developed in a deep-marine phreatic environment, as discussed next.

\section{DEEP-MARINE DIAGENESIS}

\section{Petrography}

Shallow-marine cements are the only cements that occur in small $(<0.1 \mathrm{~mm})$ shelter and intragranular pores. In larger pores, clear, fine to medium (150-200 $\mu \mathrm{m})$, equant calcite spar occurs as a late generation cement (Figs. 2 and 4 ); equant spar is

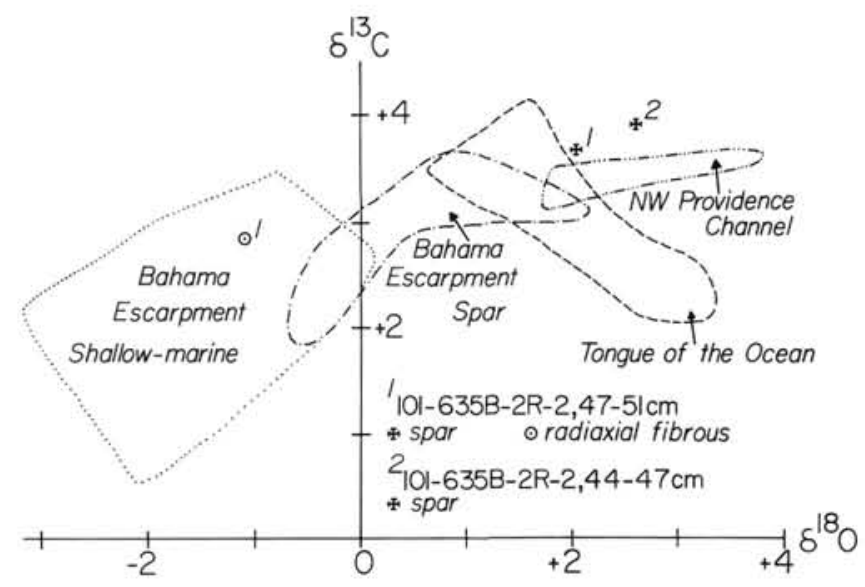

Figure 5. Stable oxygen and carbon isotopic compositions (symbols) of shallow-marine, cloudy, isopachous, fine to medium, radiaxial fibrous cement and deep-marine, clear, equant calcite spar in Oligocene-Miocene perireef boundstone clasts recovered from Hole 635B during Leg 101 from canyon-fill sediments. Isotopic composition fields determined for original shallow-marine components and deep-marine equant spars in shallow-water limestones of Early and middle Cretaceous age exposed on the Bahama Escarpment (after Freeman-Lynde et al., 1986) and of deep-marine cemented hardgrounds of Pleistocene age from Tongue of the Ocean (after Schlager and James, 1978) and Northwest Providence Channel (after Mullins et al., 1980) are shown by broken lines. Bahama Escarpment deep-marine spars are thought to have precipitated during the Maestrichtian and throughout the Cenozoic (Freeman-Lynde et al., 1986). Lighter values $\left(-0.5 \% 0 \delta^{18} \mathrm{O},+2.0 \% 0 \delta^{13} \mathrm{C}\right.$ to $+1.0 \% 0 \delta^{18} \mathrm{O},+3.0 \% \delta^{13} \mathrm{C}$ ) are typical of spars formed during the Cretaceous and Tertiary, whereas spars precipitated during Pleistocene time have heavier values $\left(+1.0\right.$ to $+2.0 \% \delta^{18} \mathrm{O},+3.0$ to $\left.+3.5 \% 0 \delta^{13} \mathrm{C}\right)$. 
the only cement occurring in molds, primarily those of whole gastropods (Fig. 6). Medium (0.1-0.25 mm) pores are filled completely by cement, but pores larger than $0.25 \mathrm{~mm}$ remain partially open.

Petrographically similar equant spar occurs in Early and middle Cretaceous shallow-bank limestones exposed on the $\mathrm{Ba}$ hama Escarpment (Freeman-Lynde et al., 1986) and buried in the subsurface of Texas (Moldovanyi and Lohmann, 1984; Prezbindowski, 1985). The spar from the Bahama Escarpment is interpreted as cement precipitated from deep-marine water in deep-burial zones and at the deep seafloor. Spar from the Cretaceous of Texas is thought to have precipitated from meteoric and connate fluids in burial phreatic environments. Meteoric-connate and deep-marine equant spars can be distinguished only by geochemical data. Equant spar in our perireef boundstone clasts could have precipitated from meteoric phreatic water during early diagenesis before downslope transportation. Or it could have precipitated from deep-marine water after the clasts were moved downslope. To resolve its origin, a microsample of this spar was taken from each clast to analyze for stable oxygen and carbon isotopic composition.

\section{Stable Oxygen and Carbon Isotopic Composition}

We contend that stable oxygen and carbon isotopic compositions $\left(+2.0 \% 0 \delta^{18} \mathrm{O},+3.6 \% 0 \delta^{13} \mathrm{C}\right.$ and $+2.6 \% 0 \delta^{18} \mathrm{O},+3.9 \% 0$ $\delta^{13} \mathrm{C}$ ) (Table 1; Fig. 5) support a deep-marine phreatic origin, rather than a meteoric phreatic origin, for equant spar in these clasts for the following reasons:

1. $\delta^{18} \mathrm{O}$ values for these equant spars are considerably heavier $(>3 \%$ ) (Table 1) than those determined for the shallow-marine cement microsample, an unusual trend for diagenesis in a meteoric phreatic environment. Freeman-Lynde et al. (1986), however, showed that equant spar precipitated from deep-marine water into Early and middle Cretaceous platform-interior limestones exposed on the Bahama Escarpment is ${ }^{18} \mathrm{O}$-enriched $(1-2 \%)$ relative to shallow-marine components (Fig. 5).
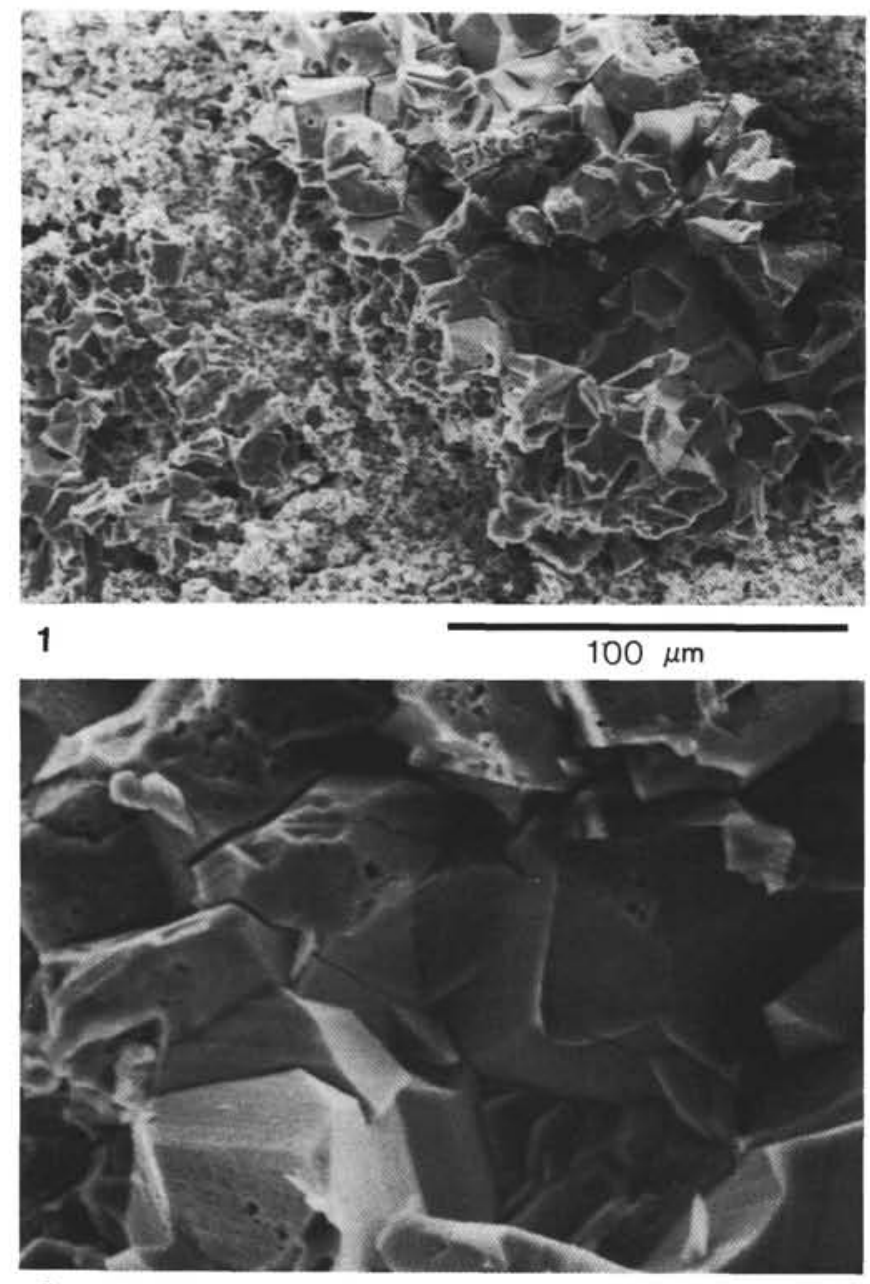

2

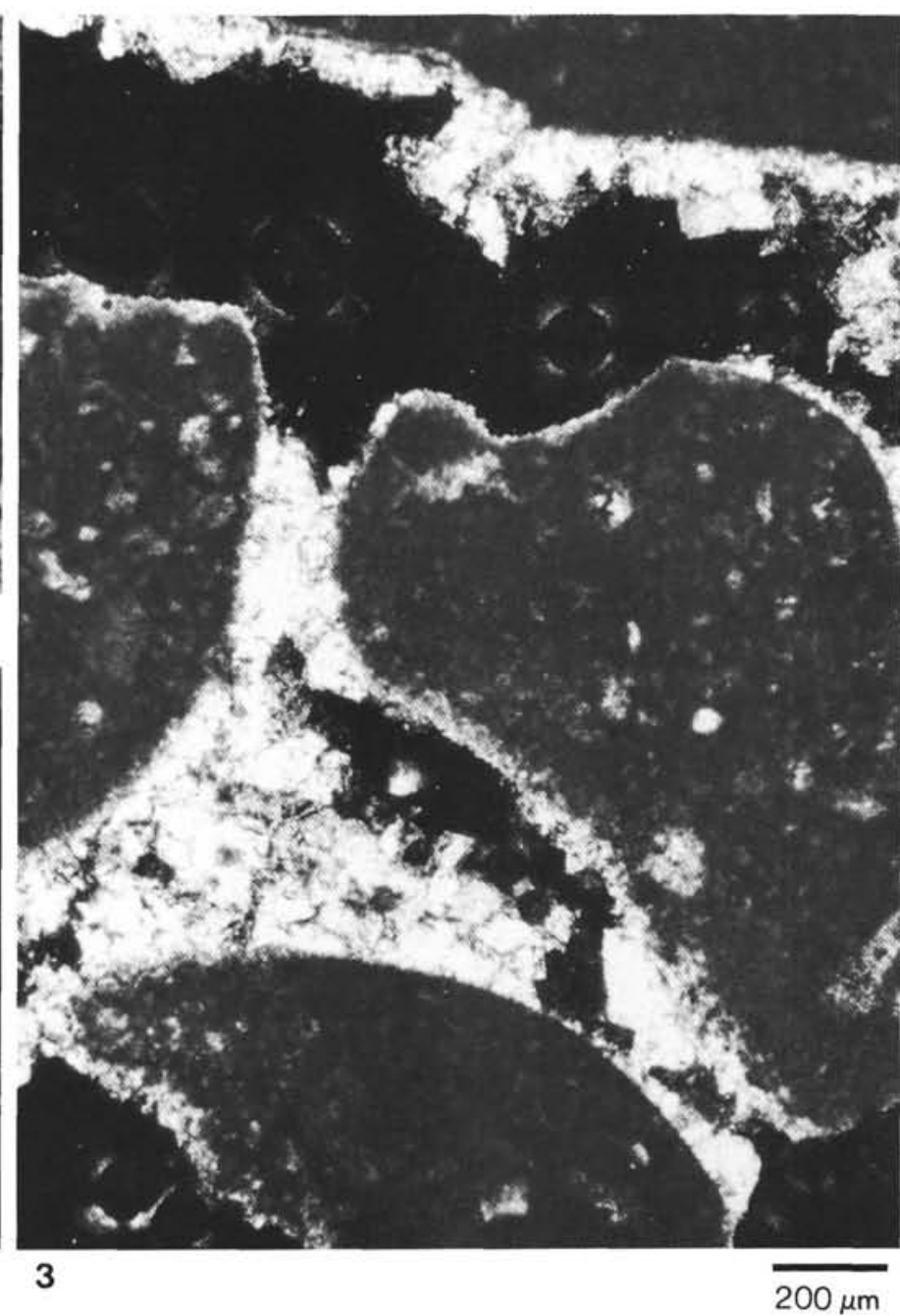

$200 \mu \mathrm{m}$

Figure 6. Thin-section and SEM photomicrographs illustrating clear, medium to coarse, equant spar precipitated from deep-marine water at the seafloor and secondary porosity (whole gastropod molds) in Oligocene-Miocene perireef boundstone clast (Sample 101-635B-2R-2, 44-47 cm) recovered from canyon-fill sediments. 1. SEM photomicrograph of equant spar in round mold. 2. Enlargement of equant spar crystals shown in SEM photomicrograph (1). Note striations on crystal faces. Such striations are not common for spar precipitated in meteoric phreatic environments. Origin of small holes in crystal faces is unclear. 3. Thin-section photomicrograph showing equant spar partially filling whole gastropod mold. Note absence of early, shallow-marine radiaxial fibrous cements shown in Figure 3. (Crossed nicols.) 
2. Heavy $\delta^{18} \mathrm{O}$ values are consistent with precipitation in equilibrium with cold $\left(5^{\circ}-15^{\circ} \mathrm{C}\right)$, deep-marine waters $\left(\delta^{18} \mathrm{O}_{\text {SMOw }}=\right.$ $0)$. Such heavy $\delta^{18} \mathrm{O}$ values would require very cold temperatures (near $0^{\circ} \mathrm{C}$ ) for precipitation in equilibrium with ${ }^{18} \mathrm{O}$-depleted meteoric waters, an unlikely situation because meteoric waters are warm $\left(20^{\circ}-25^{\circ} \mathrm{C}\right)$, as in south Florida (Kohout, 1965, 1967), for example.

3. Isotopic values of equant spar in these clasts are similar to those of deep-marine cemented hardgrounds of Pleistocene age in Tongue of the Ocean (Schlager and James, 1978) and Northwest Providence Channel (Mullins et al., 1980) and to the Pleistocene part of the isotopic field for Bahama Escarpment deep-marine spars (Fig. 5), suggesting Pleistocene deep-marine cementation of these clasts. Bahama Escarpment deep-marine spars precipitated in the Miocene and Oligocene are isotopically lighter than spars precipitated in the Pleistocene.

\section{DISCUSSION}

Our results suggest that Oligocene-Miocene perireef algal-foraminifer boundstone clasts recovered from canyon-fill sediments from Hole 635B in Northeast Providence Channel during Leg 101 have a relatively straightforward diagenetic history. Deposition occurred in a perireef setting during the Oligocene-Miocene. Initial lithification began syndepositionally. Early cementation took place in a shallow-marine phreatic environment, where cloudy, isopachous, very fine to medium, radiaxial fibrous and bladed cements (aragonite or high-magnesium calcite) were precipitated in shelter and intragranular pores and cavities. Shallow diagenesis only partially filled primary porosity, however. The incomplete filling of primary porosity by early diagenetic processes recently was documented for the carbonate section in south Florida (Schmoker and Halley, 1982; Halley and Schmoker, 1983).

Following early diagenesis, these clasts were transported downslope into a deep-marine phreatic diagenetic environment. The slumped canyon-fill unit from which these clasts were recovered is underlain by apparently in-situ middle Pliocene ooze and overlain by undisturbed sediments of early to middle Pleistocene age (Austin, Schlager, et al., 1986). Thus, emplacement of the slumped material occurred between the middle Pliocene and early Pleistocene. Whether the clasts were moved downslope at this time or had been transported into deep water before emplacement of the slumped canyon-fill unit is unclear.

Development of moldic porosity by dissolution of unstable, presumably aragonitic, grains in cold, corrosive, deep-marine water apparently occurred following downslope transportation. If moldic porosity had formed in a shallow, meteoric phreatic environment, either equant spar with isotopic compositions lighter than shallow-marine cements or shallow-marine cements should occur in molds. However, moldic porosity contains only equant spar with a deep-marine isotopic signature, indicating that the clasts were removed from shallow diagenetic environments before moldic porosity developed. Dissolution of aragonitic, but not calcitic, components should occur at Site 635 because the aragonite compensation depth is about $3000 \mathrm{~m}$ deep here, while the calcite compensation depth is deeper than $5000 \mathrm{~m}$ (Berger, 1978; Broecker and Peng, 1982). Droxler et al. (1983) showed that aragonite dissolution was more intense during glacial periods throughout the late Pleistocene. Stabilization of the originally aragonitic or high-magnesium calcitic shallow-marine cements to calcite probably occurred at this time as well.

Clear, fine to medium, equant calcite spar then precipitated from deep-marine water into newly opened moldic porosity, as well as into partially filled shelter and intragranular porosity. Larger pores remained open even after this episode of cementation. The source of carbonate for this deep-marine equant spar was apparently dissolved aragonite grains. Because such grains were not particularly abundant in these clasts, only a small amount of carbonate was generated; it was insufficient to fill both newly opened molds and partially filled shelter and intergranular pores.

\section{SUMMARY}

1. Oligocene-Miocene perireef algal-foraminifer boundstone clasts recovered in canyon-fill sediments from Hole 635B during Leg 101 contain significant quantities of cement precipitated in the shallow-marine phreatic zone. Both petrographic characteristics (isopachous, cloudy, radiaxial fibrous crystals) and stable oxygen and carbon isotopic composition $\left(-1.1 \%_{0} \delta^{18} \mathrm{O},+2.8 \%\right.$ $\delta^{13} \mathrm{C}$ ) support a shallow-marine origin for this cement. Shallow diagenesis left considerable porosity unfilled. Evidence for meteoric phreatic and vadose zone diagenesis is absent.

2. Moldic porosity developed in cold, deep-marine water by dissolution of unstable, presumably aragonitic, grains in cold, deep-marine water. Stabilization of shallow-marine cements probably occurred here as well. The limited amount of carbonate generated by dissolution of unstable grains reprecipitated into newly opened molds and partially filled primary porosity as equant calcite spar. Stable oxygen and carbon isotopic values $\left(+2.0 \%_{0} \delta^{18} \mathrm{O},+3.6 \%_{0} \delta^{13} \mathrm{C}\right.$ and $\left.+2.6 \%_{0} \delta^{18} \mathrm{O},+3.9 \%_{0} \delta^{13} \mathrm{C}\right)$ of deep-marine cement microsamples support a deep-marine origin for this spar.

\section{ACKNOWLEDGMENTS}

This study was conducted with funds provided by JOI U.S. Science Advisory Committee through the Texas A\&M University Research Foundation (purchase order 70738, project 1892-A01) and by the U.S. Office of Naval Research, contract N00014-85-K-0433, to the University of Georgia. We acknowledge the professionalism of the Master and crew of the JOIDES Resolution (SEDCO/BP 471) and of the ODP scientific and technical staff at sea. We thank D. Detman of the University of Michigan for isotope analyses. This paper was reviewed by C. St. G. Kendall and L. S. Land.

\section{REFERENCES}

Andrews, J. E., Shepard, F. P., and Hurley, R. J., 1970. Great Bahama Canyon. Geol. Soc. Am. Bull., 81:1061-1078.

Austin, J. A., Jr., Schlager, W., et al., 1986. Proc. ODP, Init. Repts. (Pt. A), 101: College Station, TX (Ocean Drilling Program).

Berger, W. H., 1978. Deep-sea carbonate: pteropod distribution and the aragonite compensation depth. Deep Sea Res., 25:447-452.

Broeker, W. S., and Peng, T.-H., 1982. Tracers in the Sea: Palisades, NY (Lamont-Doherty Geol. Observ. Publ.).

Craig, H., 1957. Isotopic standards for carbon and oxygen and correction factors for mass spectrometric analyses of carbon dioxide. Geochim. Cosmochim. Acta, 12:133-149.

Droxler, A. W., Schlager, W., and Whallen, C. C., 1983. Quaternary aragonite cycles and oxygen-isotope record in Bahamian carbonate ooze. Geology, 11:235-239.

Freeman-Lynde, R. P., Whitley, K. F., and Lohmann, K. C., 1986. Deep-marine origin of equant spar cements in Bahama Escarpment limestones. J. Sediment. Petrol., 56:799-811.

Frost, S. H., 1981. Oligocene reef coral biofacies of the Vicentin, northeast Italy. In Toomey, D. F. (Ed.), European Fossil Reef Models: Soc. Econ. Paleontol. Mineral. Spec. Publ., 30:483-539.

Frost, S. H., and Langenheim, R. L., Jr., 1974. Cenozoic Reef Biofacies. Tertiary Larger Foraminifera and Scleractinian Corals from Chapias, Mexico: DeKalb, IL (Northern Illinois Univ. Press).

Halley, R. B., and Schmoker, J. W., 1983. High-porosity Cenozoic carbonate rocks of south Florida: progressive loss of porosity with depth. AAPG Bull., 67:191-200.

Kohout, F. A., 1965. A hypothesis concerning cyclic flow of salt water related to geothermal heating in the Floridan Aquifer. Trans. N.Y. Acad. Sci., ser. 2, 28:249-271.

1967. Ground-water flow and the geothermal regime of the Floridian Plateau. Trans. Gulf Coast Assoc. Geol. Soc., 17:339354. 
Longman, M. W., 1980. Carbonate diagenetic textures from nearsurface diagenetic environments. AAPG Bull., 64:461-487.

Moldovanyi, E. P., and Lohmann, K. C., 1984. Isotopic and petrographic record of phreatic diagenesis: Lower Cretaceous Sligo and Cupido Formations. J. Sediment. Petrol., 54:972-985.

Mullins, H. T., Neumann, A. C., Wilber, R. J., and Boardman, M. R., 1980. Nodular carbonate sediment on Bahamian slopes: possible precursors to nodular limestones. J. Sediment. Petrol., 50:117-131.

Murray, J. W., 1973. Distribution and Ecology of Living Benthic Foraminiferids: New York (Craine, Russak and Co.).

Prezbindowski, D. R., 1985. Burial cementation-is it important? A case study, Stuart City Trend, south central Texas. In Schneidermann, N., and Harris, P. M. (Eds.), Carbonate Cements: Soc. Econ. Paleontol. Mineral. Spec. Publ., 36:241-264.

Ross, C. A., 1979. Ecology of large, shallow-water, tropical foraminifera. In Foraminiferal Ecology and Paleoecology: Soc. Econ. Paleontol. Mineral. Short Course, Houston, 1979, 6:54-61.
Schlager, W., and James, N. P., 1978. Low-magnesian calcite limestones forming at the deep-sea floor, Tongue of the Ocean, Bahamas. Sedimentology, 25:675-702.

Schlager, W., Hoole, R. L., and James, N. P., 1976. Episodic erosion and deposition in the Tongue of the Ocean (Bahamas). Geol. Soc. Am. Bull., 87:1115-1118.

Schmoker, J. W., and Halley, R. B., 1982. Carbonate porosity versus depth: a predictable relation for south Florida. AAPG Bull., 66: 2561-2570.

Scholle, P. A., and Halley, R. B., 1985. Burial diagenesis: out of sight, out of mind!. In Schneidermann, N., and Harris, P. M. (Eds.), Carbonate Cements: Soc. Econ. Paleontol. Mineral. Spec. Publ., 36: 309-334.

Date of initial receipt: 14 November 1986

Date of acceptance: 30 June 1987

Ms 101B-173 